\title{
Herpes Zoster Oticus
}

National Cancer Institute

\section{Source}

National Cancer Institute. Herpes Zoster Oticus. NCI Thesaurus. Code C84763.

A viral ear infection caused by the spread of varicella-zoster virus to the facial nerves. It is characterized by intense otalgia and a cutaneous vesicular eruption. 